\title{
Mengelola Konflik Sosial Melalui Penguatan Kelembagaan Desa Di Kabupaten Bone
}

\author{
Managing Social Conflicts Through Strengthening Village Institutions In Bone District \\ Muh. Iqbal Latief. ${ }^{1}$; Arsyad Genda ${ }^{2}$ Suryanto $^{3}$; Arini Enar Lestari AR ${ }^{4} *$ \\ 1.2.3,4 Departemen Sosiologi, Fakultas Ilmu Sosial dan Ilmu Politik Universitas Hasanuddin \\ Email: muhilberkelana@gmail.com ${ }^{1}$; garsyad@gmail.com ${ }^{2}$; suryanto.sosiologiunhas@gmail.com ${ }^{3}$, arini.ardani@unhas.ac.id
}

\section{ART I CLE IN FO}

\section{How to Cite:}

Latief, M. I., Genda, A., Suryanto, \& Lestari AR, A. E.

L. (2019). Mengelola Konflik

Sosial Melalui Penguatan

Kelembagaan Desa di

Kabupaten Bone. Hasanuddin

Journal of Sociology (HJS),

1(2), 88-100

\section{Keywords: \\ Conflict, Institution, Village, \\ Community}

\section{Kata Kunci :}

Konflik, Kelembagaan,

Masyarakat, Desa

\begin{abstract}
A B S T RA C T
Conflict management that has been mostly done tends to be reactive and short-term because it only tends to respond to conflict problems that appear on the surface and are secondary in nature so that they can sporadically reappear. Therefore, the handling of conflicts that are long-term in order to be able to prevent and reduce conflicts that occur is something that is very urgent to be done by all parties including tertiary institutions. In general, in the Regency of Bone there has been a conflict which is motivated by various factors such as land issues, politics and even related to religious values and beliefs. As partners in this activity are the government and village communities in Bone Regency. So that through this conflict management training will produce a conflict management document. This activity is carried out from April to September 2019, starting from the formulation of proposals to the preparation of the final report of activities. The solutions and methods used in this training are the provision of knowledge and understanding through lectures and questions and answers, the practice of mapping potential conflicts with prepared tools and formulating steps for conflict management that potentially occur in the community.
\end{abstract}

\begin{abstract}
ABSTRAK
Pengelolaan konflik yang telah banyak dilakukan cendrung bersifat reaktif dan jangka pendek karena hanya cendrung merespon permasalahan konflik yang nampak dipermukaan dan bersifat sekunder saja sehingga secara sporadis dapat muncul kembali. Oleh karena itu, penanganan konflik yang bersifat jangka panjang untuk bisa mencegah dan meredam konflik yang terjadi merupakan suatu hal yang sangat urgen untuk dilakukan oleh semua pihak termasuk lembaga perguruan tinggi. Secara umum di Kabupaten Bone telah terjadi konflik yang dilatar belakangi berbagai macam faktor seperti permasalahan tanah, politik bahkan terkait dengan nilai agama dan
\end{abstract}


kepercayaan. Sebagai mitra dalam kegiatan ini adalah pemerintah dan masyarakat Desa di Kabupaten Bone. Sehingga melalui pelatihan pengelolaan konflik ini akan menghasilkan suatu dokumen pengelolaan konflik. Kegiatan ini dilaksanakan mulai bulan April sampai dengan September 2019 yang dimulai dari perumusan proposal sampai dengan penyusunan laporan akhir kegiatan. Solusi dan metode yang digunakan dalam pelatihan ini adalah pemberian pengetahuan dan pemahaman melalui ceramah dan tanya jawab, praktek melakukan pemetaan potensi konflik dengan alat yang disiapkan serta merumuskan langkah-langkah pengelolaan konflik yang berpotensi terjadi di masyarakat.

(C) 2019 Hasanuddin Journal of Sociology. All rights reserved.

\section{PENDAHULUAN}

Beragamnya isu konflik yang terjadi baik skala lokal maupun nasional sebagai konsekuensi dari realitas bangsa yang majemuk secara kultur, etnis, ras, agama dan aliran kepercayaan. Masyarakat dan Bangsa Indonesia lahir melaui proses pembentukan karakter kebangsaan yang kuat dengan melewati beragam fase konflik bahkan pertempuran-pertempuran dahsyat baik pada ketika masa kerajaan nusantara sampai pada masa mempertahankan negara kesatuan Indonesia. Masyarakat dan Bangsa Indonesia dapat berdiri dengan kokoh justru karena adanya kemajemukan dan setiap unsur yang berbeda masing-masing memiliki kesadasan fundamental yang sama tentang pentingnya persatuan dan kesatuan bangsa, pentingnya kedamaian di atas semua kepentingan unsur dan golongan.

Dengan modal kemajemukan tersebut Bangsa Indonesia akan menjadi salah satu bangsa terkuat di dunia selama nilai-nilai kemajemukan tersebut dapat dikelola secara produktif dengan menjunjung tinggi harkat dan martabat kemanusiaan, sebagaimana telah ditegaskan dalam Pancasila sebagai Dasar Negara Indonesia. Sebagai suatu modal maka kemajemukan perlu dirawat sampai pada level masyarakat paling bawah dengan pendekatan yang menyentuh aspek kelembagaannya. Kelembagaan yang paling strategis adalah keluarga khususnya ditingkat rumah tangga karena pada lembaga ini proses sosialisasi dan pendidikan paling pertama dilakukan.

Menurut UU No 6 Tahun 2014 tentang Desa, Kelembagaan Desa teridri ataas: Kepala Desa, Perangkat Desa, Badan Permusyawaratan Desa (BPD). Kelembagaan Desa tersebut memiliki peranann yang sangat penting untuk mendoroong roda pembangunan di wilayahnya. Dalam perkembangan tidak menutup kemungkinan adanya berbagai gejolak dan reaksi dari berbagai pihak baik secara internal maupun secera eksternal. Hal tersebut membutuhkan manajemen untuk pengelolaan konflik sehingga konflik yang terjadi bisa diatasi.

\section{METODE PENELITIAN}

Dalam pelaksanaan kegiatan ini yang merupakan sumber informasi adalah masyarakat sebagai 
Subjek bukan sebagai Objek. Prinsip yang dibangun adalah POD (pembelajaran Orang Dewasa) dimana fasilitator bertindak dan mengarahkan jalannya diskusi bukan sebagai sumber belajar akan tetapi bersama-sama berdiskusi mememcahkan persolan bersama. Adapun metodologi yang dipakai dalam pelatihan yaitu:

1. FGD/DKT (Focus Group Diskusssion/ Diskusi Kelompok Terarah), dimana peserta terlibat dengan jumlah. 9 - 15 Orang, ada yang bertindak sebagai fasilitator dan notulensi.

2. PRA (Partisipatory Rural Apprasial), dimana yang menjadi penekanan dalam pelatihan ini menggunakan 3 alat kajian utama yaitu:

a. Matriks Waktu Luang: dalam matriks ini peserta belajar bersama dalam memetakan dan menganalisis waktu luang dalam 1 × 24 jam untuk aktivitas ibu rumah tangga, kegiatan mingguan dan waktu luang yang dapat dipakai dalam kegiatan rembug/musyawarah di Desa Timbuseng.

b. Diagram Venn : dalam diagram ini peserta belajar bersama dalam memetakan kelembagaan/kelompok/perkumpulan/organisasi/sejenisnya, berdasarkan besar dan kecilnya organisasi tersebut, dapat dilihat berdasarkan struktur kepengurusan organisasi, legalitas. Dan hubungan serta manfaat langsung yang dirasakan oleh masyarakat, semakin dekat hubungan kelembagaan/ kelompok/ perkumpulan/ organisasi/ sejenisnya tersebut menunjukkan manfaat langung yang rasakan demikian pula sebaliknya.

c. Matriks Potensi, Masalah dan Alternatif Pemecahan Masalah : dalam matriks ini peserta belajar bersama untuk menemukenali/ menganalisis akar penyebab persoalan konflik yang dihadapi serta memetakan potensi pemecahan masalah serta mencari alternatif pemecahan masalah.

d. Ceramah : dalam kegiatan ini akan diharapakan memberikan informasi kepada peserta terkait penguatan kelembagaan desa untuk deteksi dini untuk pencegahan konflik.

\section{HASIL DAN PEMBAHASAN}

\section{- Konflik}

Konflik adalah aspek intrinsik dan tidak mungkin dihindarkan dalam perubahan sosial. Konflik adalah sebuah ekspresi heterogenitas kepentingan, nilai, dan keyakinan yang muncul sebagai formasi baru yang ditimbulkan oleh perubahan sosial yang muncul bertentangan dengan hambatan yang diwariskan. Namun cara kita menangani konflik adalah persoalan kebiasaan dan pilihan.

Konflik merupakan bagian dari kehidupan umat manusia yang tidak pernah dapat diatasi sepanjang sejarah umat manusia. Sepanjang seseorang masih hidup hampir mustahil untuk 
menghilangkan konflik di muka bumi ini. Konflik antar perorangan dan antar kelompok merupakan bagian dari sejarah umat manusia. Berbagai macam keinginan seseorang dan tidak terpenuhinya keinginan tersebut dapat juga berakhir dengan konflik. Perbedaan pandangan antar perorangan juga dapat mengakibatkan konflik.

Konflik menyebabkan terjadinya interaksi pada tataran yang lebih serius dari sekedar kompetisi. Meskipun, sebagaimana yang dinyatakan Schelling bahwa konflik, kompetisi, dan kerjasama pada dasarnya saling berkaitan. Konflik terjadi manakala tujuan, kebutuhan, dan nilai-nilai kelompok yang bersaing bertabrakan dan akibatnya terjadilah agresi, walaupun belum tentu berbentuk kekerasan. Sebuah konflik sering berawal dari persoalan kecil dan sederhana. Perbedaan pendapat dan sikap termasuk ketidakinginan untuk menerima orang lain, dapat menyebabkan konflik antara seseorang dan yang lainnya.

Pada umumnya konflik diakibatkan oleh perbedaan pendapat, pemikiran, ucapan dan perbuatan. Sikap dasar yang sulit dan tidak ingin menerima dan menghargai perbedaan semacam itu akan mengubah seseorang berwatak berkonflik. Orang seperti ini akan membuat problem kecil dan sederhana sebagai alasan untuk menciptakan konflik. Konflik menjadi saluran dari akumulasi perasaan yang tersembunyi secara terusmenerus yang mendorong seseorang untuk berperilaku dan melakukan sesuatu berlawanan dengan orang lain.

Sebuah keinginan ambisi yang kuat akan menyebabkan terjadinya konflik antarperorangan, sedangkan dorongan emosi yang kuat untuk menyalahkan orang lain akan menyebabkan seseorang terlibat konflik dengan orang lain.

Sedangkan Teori konflik di sini dapat dikatakan sebagai bahan acuan dalam melihat lebih jauh tentang konflik, baik dari alasan terjadi hingga cara-cara penyelesaian konflik tersebut.

Marxisme dalam teori rekayasa sosial menggunakan teori konflik yang digunakan dalam analisis sosial, fenomena masyarakat dieksplorasi dengan menerjemahkan bagaimana relasi yang ada dalam struktur masyarakat dalam memberikan makna bagi individualis dalam mereduksi otonomi individualis.

Sedangkan dalam pandangan teori konflik yang diakui oleh Marxisme, menggagaskan dalam pandangannya bahwa proses perhelatan yang terjadi dalam struktur masyarakat berlandaskan atas pertentangan kelas, kekuasaan dan kepentingan lainnya sehingga membentuk perubahan sosial. Marxisme dalam teori rekayasa sosial menggunakan teori konflik yang digunakan dalam analisis sosial, fenomena masyarakat dieksplorasi dengan menejermahkan bagaimana relasi yang ada dalam struktur masyarakat dalam memberikan makna bagi individualis dalam mereduksi otonomi individualis.

Sedangkan dalam pandangan teori konflik yang diakui oleh Marxisme, menggagaskan dalam pandangannya bahwa proses perhelatan yang terjadi dalam struktur masyarakat berlandaskan atas 
pertentangan kelas, kekuasaan dan kepentingan lainnya sehingga membentuk perubahan sosial.

Teori konflik dan ideologi Marxin akan tumbuh subur jika adanya kondisi suatu masyarakat yang merasa disubordinat oleh masyarakat lain sehingga memungkinkan terjadinya sebuah konflik untuk saling memperebutkan kekuasaan. Dalam artian bagaimana kelompok yang menjadi subordinat bisa mengambil kekuasaan dari kelompok yang dominan dan cenderung melakukan tindakan destruktif terhadap kelompok subordinat sehingga kelompok itu dapat bebas dari eksploitasi yang cenderung destruktif.

Pandangan Dahrendorf (dalam Ritzer 2003:153) berpendirian bahwa masyarakat mempunyai dua wajah (konflik dan konsensus). Teori konsensus harus meguji nilai integrasi dalam masyarakat dan teori konflik harus menguji konflik dan penggunaan kekerasan yang mengikat masyarakat bersama di hadapan tekanan itu. Dahrendorf mengakui bahwa masyarakat takkan ada tanpa konsensus dan konflik yang menjadi persyaratan satu sama lain. Jadi kita tak akan punya konflik kecuali ada konsensus sebelumnya.

Selain itu pandangan Dahrendorf yang memusatkan perhatian pada struktur sosial yang lebih luas. Inti tesisnya adalah gagsan bahwa berbagai posisi di dalam masyarakat mempunyai kualitas otoritas yang berbeda. Otoritas tidak terletak di dalam masyarakat mempunyai kualitas otoritas yang berbeda . otoritas tidak terletak di dalam diri individu, tetapi di dalam posisi. Dahrendorf tak hanya tertarik pada struktur posisi, tetapi juga konflik antara berbagai struktur posisi itu: "sumber struktur konflik harus dicari di dalam tatanan peran sosial yang berpotensi untuk mendominasi atau ditundukkan". Menurut Dahrendorf, tugas pertama analisis konflik adalah mengidentifkasi berbagai peren otoritas di dalam masyarakat. Karena memusatkan perhatian pada struktur bersakala luas seperti peran otoritas itu.

Otoritas yang melekat pada posisi adalah unsur kunci dalam analisis Dahrendorf. Otoritas secara tersirat menyatakan superordinasi dan subordinasi. Mereka yang menduduki posisi otoritas diharapkan mengandalkan bawahan. Artinya, mereka berkuasa karena harapan dari orang yang berada di sekitar mereka, bukan karena ciri-ciri psikologis mereka sendiri. Seperti otoritas, harapan ini pun melekat pada posisi, bukan pada orangnya. Otoritas bukanlah fenomena sosial yang umum, mereka yang tunduk pada kontrol dan mereka yang dibebaskan dari kontrol, ditentukan oleh masyarakat. Terakhir, karena otoritas adalah abash sanksi dapat dijatuhkan pada pihak yang menentang.

Menurut Dahrendorf, otoritas tidak konstan karena ia terletak dalam posisi, bukan di dalam diri orangnya. Karena itu seseorang yang berwenang dalam satu lingkungan tertentu tak harus memegang posisi otoritas di dalam lingkungan yang lain. Begitu pula seseorang yang berada dalam posisi subordinat dalam satu kelompok, mungkin menempati posisi yang superodinat dalam kelompok lain. 
Ini berasal dari argument Dahrendorf yang menyatakan bahwa masyarakat tersusun dari sejumlah unit yang ia sebut asosiasi yang dikoordinasikan secara imperatif. Masyarakat terlihat sebagai asosiasi individu yang terkontrol oleh hierarki posisi otoritas. Karena masyrakat terdiri dari berbagai posisi, seorang individu dapat menempati posisi otoritas di satu unit dan menempati posisi yang subordinat di unit lain.

Otoritas dalam setiap asosiasi bersifat dikotomi, karena itu ada dua, hanya ada dua, kelompok konflik yang dpat terbentuk di dalam setiap asosiasi. Kelompok yang memegang posisi otoritas dan kelompok subordinat yang mempunyai kepentingan tertentu "yang arah dan substansinya saling bertentangan”. Di sini kita berhadapan dengan konsep kunci lain dalam teori konflik Dahrendorf, yakni kepentingan. Kelompok yang berada diatas dan yang berada di bawah didefinisikan berdasarkan kepentingan bersama. Dahrendorf tetap menyatakan bahwa kepentingan itu, yang sepertinya tampak sebagai fenomena psikologis, pada dasarnya adalah fenomena bersakala luas.

Untuk tujuan analisis sosilogi tentang kelompok konflik dan konflik kelompok, perlu menganut orientasi structural dari tindakan pemegangan posisi tertentu. Dengan analogi terhadap orientasi kesadaran (subjektif), tampaknya dapat dibenarkan untuk mendeskripsikan ini sebagai kepentingan....asumsi kepentingan (objektif) yang diasosiasikan dengan posisi social tidak meengandung ramifikasi atau implikasi psikologis, ia termasuk dalam level analisis sosiologis (Dahrendorf dalam Ritzer, 2003:156).

Pemikiran awal tentan fungsi konflik sosial berasal dari Georg Simmel, tetapi diperluas oleh Coser (Ritzer, 2003:159) yang menyatakan bahwa konflik dapat membantu mengeratkan ikatan kelompok yang berstruktur secara longgar. Masyarakat yang mengalami disintegrasi, atau berkonflik dengan masyarakat lain, dapat memperbaiki kepaduan integrasi.

Konflik dilihat dari segi status pihak yang bertikai dibedakan atas :

a. Konflik simetris adalah konflik yang terjadi diantara pihak-pihak yang relatif sama kepentingannya. Contoh, mahasiswa dengan sesama mahasiswa, pengusaha dengan sesama pengusaha.

b. Konflik tidak simetris adalah konflik yang muncul diantara pihak-pihak yang tidak sama kepentingannya. Contohnya, konflik yang terjadi antara kaum mayoritas dengan kaum minoritas, pemerintahan dengan sekelompok pemberontak, seorang majikan dengan karyawannya, dan lain-lain.

Konflik dilihat dari segi asal permasalahan dibedakan atas :

a. Konflik Realistis yaitu konflik yang berasal dari kekecewaan terhadap tuntutan tuntutan khusus yang terjadi dalam hubungan dan dari perkiraan kemungkinan keuntungan pare 
partisipan, dan yang ditujukan pada objek yang dianggap mengecewakan. Contoh, para karyawan yang mengadakan pemogokan melawan manajemen, sejauh manajemen memang berkuasa dalam hal kenaikan gaji serta berbagai keuntungan buruh lainnya.

b. Konflik tidak Realistis yaitu konflik yang terjadi bukan dari tujuan-tujuan saingan yang antagonis, tetapi dari kebutuhan untuk meredakan ketegangan, paling tidak dari salah satu pihak. Contoh, masih digunakannya ilmu gaib dalam kehidupan masyarakat untuk menyelesaikan masalahnya seperti balas dendam, sehingga akan muncul seorang kambing hitam dari proses prasangka.

Ada beberapa metode/cara yang dapat menjadi alteratif untuk menyelesaikan suatu konflik diantaranya adalah :

a. Dengan melakukan pendekatan. Sudah menjadi kebiasaan khas dalam konflik adalah memberikan prioritas yang tinggi guna mempertahankan kepentingan pihaknya sendiri, sehingga jika kepentingan A bertentangan dengan kepentingan B, maka A cenderung mengabaikan B, atau secara aktif menghancurkannya. Pendekatan disini dibedakan oleh apakah perhatian bagi diri sendiri atau perhatian bagi orang lain itu tinggi atau rendah.

b. Dengan mengalah. Ini mengimplikasikan perhatian yang lebih terhadap kepentingan pihak lain kepentingan diri sendiri.

c. Menghindari konflik dan mengundurkan diri. Ini menunjukkan kepedulian yang rendah pada diri sendiri dan pihak lain.

d. Mencari kompromi dan mencoba mengakomodasikan kepentingan kedua belah pihak. Ini lebih menyeimbangkan perhatian pada diri sendiri dan pihak lain.

e. Memberi penghargaan yang tinggi bagi kepentingan diri sendiri dan pihak lain. Ini mengimplikasikan penegasan yang kuat terhadap kepentingan sendiri, tetapi juga menyadari aspirasi dan kebutuhan pihak lain, berusaha untuk mencari hasil penyelesaian masalah yang kreatif.

f. Dalam konflik yang strukturnya tidak simetris, yang kuat selalu menang dan yang lemah selalu kalah. Satu-satunya cara untuk menyelesaikan konflik jenis ini adalah dengan mengubah strukturnya, tetapi ini merupakan keinginan dari pihak yang kuat. Sehingga di sini tidak ada hasil menang-menang, jadi pihak ketiga harus menggabungkan kekuatan dengan pihak yang lemah untuk menghasilkan pemecahan.

\section{- Mengelola Konflik}

Pendekatan kelembagaan merupakan salah satu bentuk pendekatan yang akan didorong dan 
difasilitasi melalui pelatihan khususnya pada kegiatan pengabdian masyarakat yang akan dilaksanakan di Kabupaten Bone. Pemilihan dan penetuan lokasi didasarkan pada salah satu pertimbangan bahwa di daerah tersebut telah terjadi beberapa konflik baik vertikal maupun horisontal. Secara umum gambaran konflik yang pernah terjadi di Kabupaten Bone berdasarkan hasil pemetaan daerah rawan konflik di Sulawesi Selatan khususnya di Kabupaten Bone yang dilaksanakan oleh Dinas Sosial Provinsi Sulawesi Selatan Tahun 2014 sebagai berikut:

Tabel 1.

\section{Beberapa Isu Konflik di Kabupaten Bone} Tahun 2014

\begin{tabular}{|c|c|c|c|c|c|}
\hline No. & Isu Konflik & $\begin{array}{l}\text { Lokasi } \\
\text { Konflik }\end{array}$ & $\begin{array}{l}\text { Luas Area } \\
\text { Sengketa }\end{array}$ & $\begin{array}{c}\text { Pihak-pihak } \\
\text { yang Terlibat }\end{array}$ & Deskripsi Konflik \\
\hline 1. & Lahan Hutan & $\begin{array}{l}\text { Desa Tapong } \\
\text { Kecamatan } \\
\text { Tellu Limpoe } \\
\text { Kabupaten } \\
\text { Bone dan } \\
\text { Desa Bacu- } \\
\text { bacu } \\
\text { Kabupaten } \\
\text { Barru. }\end{array}$ & $\begin{array}{l}\text { Lahan Hutan } \\
\text { Lindung }\end{array}$ & $\begin{array}{l}\text { Masyarakat Desa } \\
\text { Tapong } \\
\text { Kecamatan Tellu } \\
\text { Limpoe } \\
\text { Kabupaten Bone } \\
\text { dan } \\
\text { Desa Bacu-bacu } \\
\text { Kabupaten } \\
\text { Barru. }\end{array}$ & $\begin{array}{l}\text { Adanya perambahan hutan } \\
\text { dengan menebang pohon hutan } \\
\text { lindung. Lahan tersebut } \\
\text { merupakan sumber mata air. } \\
\text { Adanya pembiaran yang } \\
\text { dilakukan oleh aparat masing- } \\
\text { masing. Adanya saling } \\
\text { mengklaim batas-batas wilayah } \\
\text { dengan cara warga yang masuk } \\
\text { dari barru dengan informasi } \\
\text { dari warga bone begitupun } \\
\text { sebaliknya. Masyarakat kurang } \\
\text { dilibatkan yang hanya terlibat } \\
\text { adalah oknum dari aparat } \\
\text { pemerintah setempat. } \\
\text { Penduduk Desa Tapong } \\
\text { dengan jumlah } 1.318 \text { orang, } \\
\text { laki-laki } 674 \text { orang dan } \\
\text { perempuan } 644 \text { orang.Kondisi } \\
\text { sekarang berpenghuni sekitar } \\
40 \text { tempat hunian. Sudah ada } \\
\text { yang memperjual belikan } \\
\text { dengan harga } 5 . j u t a \text { dengan } \\
\text { ukuran } 15 \text { x } 20 \text { m. }\end{array}$ \\
\hline 2. & $\begin{array}{l}\text { Perang Antar } \\
\text { Kelompok }\end{array}$ & & & $\begin{array}{l}\text { Kelompok } \\
\text { Labempa dan } \\
\text { Lacokkong }\end{array}$ & \\
\hline 3. & $\begin{array}{l}\text { Konflik } \\
\text { Kampus STAI } \\
\text { Al Gazali } \\
\text { Bone }\end{array}$ & $\begin{array}{l}\text { Kec. Tanete } \\
\text { Riattang Kab. } \\
\text { Bone }\end{array}$ & & $\begin{array}{l}\text { Mahasiswa dan } \\
\text { Yayasan }\end{array}$ & $\begin{array}{l}\text { Mahasiswa menuntuk hak- } \\
\text { haknya seperti sistem anggaran } \\
\text { dan fasilitas kampus kepada } \\
\text { pihak kampus agar proses } \\
\text { perkulihan bisa berjalan } \\
\text { efektif. Ini beraikibat } \\
\text { penyegelan kampus. }\end{array}$ \\
\hline 4. & $\begin{array}{l}\text { Tapal batas } \\
\text { Desa }\end{array}$ & $\begin{array}{l}\text { Tapal batas } \\
\text { Desa Sailong }\end{array}$ & & $\begin{array}{l}\text { Masyarakat Desa } \\
\text { Sailong dengan }\end{array}$ & $\begin{array}{l}\text { Perkelahian Kelompok tentang } \\
\text { batas wilayah }\end{array}$ \\
\hline
\end{tabular}




\begin{tabular}{|c|c|c|c|c|c|}
\hline & & $\begin{array}{l}\text { dengan Desa } \\
\text { Sanrangeng } \\
\text { Kec. Dua } \\
\text { Boccoe Kab. } \\
\text { Bone } \\
\end{array}$ & & $\begin{array}{l}\text { Desa Sanrangeng } \\
\text { Kec. Dua Boccoe } \\
\text { Kab. Bone }\end{array}$ & \\
\hline 5. & Konflik Lahan & $\begin{array}{l}\text { Dusun } \\
\text { Calengke } \\
\text { Desa } \\
\text { Patimpeng } \\
\text { Kec. } \\
\text { Patimpeng, } \\
\text { Desa } \\
\text { Gattareng } \\
\text { Kec. Kahu, } \\
\text { Dusun } \\
\text { Labombo } \\
\text { Desa } \\
\text { Wanuawaru } \\
\text { Kec. Libureng } \\
\text { dan Dusun } \\
\text { Lassengkong } \\
\text { Desa Bune } \\
\text { Kec. Libureng }\end{array}$ & $\begin{array}{l}3 \text { ha, } 12 \text { ha, } \\
14 \text { ha, } 8 \text { ha, } \\
\text { dan } 200 \text { ha }\end{array}$ & $\begin{array}{l}\text { Masyarakat dan } \\
\text { PT. PTPN X } \\
\text { PGB Arasoe/ PT. } \\
\text { PTPN X PGB } \\
\text { Camming }\end{array}$ & $\begin{array}{l}\text { Sengketa lahan di Pabrik gula: } \\
\text { PT. PTPN X PGB Arasoe/ PT. } \\
\text { PTPN X PGB Camming } \\
\text { dengan masyarakat yang } \\
\text { berdampak pada Konflik } \\
\text { horizontal anatara masyarakat } \\
\text { dengan pihak perusahaan, } \\
\text { Penyanderaan barang - barang } \\
\text { perusahaan, Blokade jalan dan } \\
\text { Pengrusakan kantor dan alat - } \\
\text { alat perusahaan }\end{array}$ \\
\hline 6. & $\begin{array}{l}\text { Perkelahian } \\
\text { Kelompok }\end{array}$ & Kab. Bone & & Pemuda & $\begin{array}{l}\text { Perselisihan antara pemuda } \\
\text { Bene dan Lonrae Kec. T. R. } \\
\text { Timur Kab. Bone dan } \\
\text { perselisihan antara kelompok } \\
\text { pemuda kampung leteng } \\
\text { dengan kampung bajo dan } \\
\text { perselisihan antara Kelompok } \\
\text { Labempa dan Lacokkong }\end{array}$ \\
\hline 7. & Terorisme & Kab. Bone & & $\begin{array}{l}\text { Masyarakat dan } \\
\text { Aparat } \\
\text { Kepolisian }\end{array}$ & $\begin{array}{l}\text { Dugaan keberadaan DPO } \\
\text { teroris an. HAMDARA } \\
\text { TAHMIL di Kab. Bone yang } \\
\text { berakibat pada Aksi main } \\
\text { hakim sendiri oleh masyarakat, } \\
\text { Rekrutmen anggota teroris dan } \\
\text { Aksi teror dari DPO tersebut }\end{array}$ \\
\hline
\end{tabular}

\section{Sumber: Data Dinas Sosial Provinsi Sulawesi Selatan Tahun 2014}

Berdasarkan data tersebut bahwa masalah tanah/agraria merupkan salah satu isu yang dapat memicu terjadinya konflik sosial di masyarakat. Beberapa permasalahan agraria/tanah yang dapat menimbulkan konflik seperti pembukaan lahan perkebunan terutama yang dilakukan oleh pihak pemerintah atau swasta, penyerobotan tanah serta permasalahan tanah warisan. Isu yang lain adalah terkait dengan permasalahan politik sehingga hampir semua level pemilihan seperti pemilihan Bupati dan Kepala Desa cendrung menimbulkan konflik antar warga bahkan sesama anggota keluarga. Sikap dan pilihan politik yang tidak diikuti dengan pemahaman nilai-nilai demokrasi yang baik dan benar merupakan fakto pemicu terjadinya konflik. Permasalahan lain yang sangat berpotensi menimbulkan konflik adalah penyebaran nilai-nilai ajaran baru dalam agama yang dianggap bertentangan atau tidak 
sesuai dengan apa yang telah diyakini dan dilakukan oleh masyarakat selama ini.

Banyak pendapat para ahli mengenai konflik, sebut saja Pruitt dan Rubin (2009) yang meminjam definisi konflik menurut kamus Webster dimana konflik diartikan sebagai perkelahian, peperangan atau perjuangan yang kesemuanya itu berupa konfrontasi fisik antara beberapa pihak. Dalam penjelasan makna kata konflik kemudian dikembangkan dengan batasan bahwa konflik adalah ketidak sepakatan yang tajam atau oposisi atas berbagai kepentingan, ide dan lain-lain. Atas dasar inilah Pruitt dan Rubin mengemukakan batasan konflik sebagai persepsi mengenai perbedaan kepentingan (perceived divergence of interest), dengan kata lain, konflik merupakan suatu keyakinan bahwa aspirasi pihakpihak yang berkonflik tidak dapat dicapai secara simultan. Jadi pada intinya, konflik dapat diartikan sebagai persepsi mengenai perbedaan kepentingan (interest). Sementara kepentingan adalah perasaan seseorang mengenai apa yang susungguhnya dia inginkan. Perasaan cenderung bersifat sentral dalam pikiran dan tindakan manusia yang membentuk inti dari sikap, tujuan dan niat (intensinya).

Terkait dengan hal di atas, secara fungsional, konflik dipandang memiliki fungsi sosial yang positif seperti pendangan George Simmel dan Lewis Coser. Sementara Marx dan Ibu Khaldun memandang bahwa konflik menjadi dinamika sejarah manusia. Lain halnya dengan Max Weber dan Dahrendorf yang memandang konflik sebagai entitas hubungan sosial. Demikian pula dengan Maslow, Max Neef, John Burton dan Marshal Rosenberg yang memandang konflik sebagai bagian dari proses pemenuhan kebutuhan dasar manusia. Sementara itu, Poerwadarminta dalam Kamus Umum Bahasa Indonesia (1976) menyebutkan bahwa konflik berarti pertentangan atau percekcokan. Pertentangan bisa dalam bentuk ide maupun fisik antara dua belah pihak yang berseberangan (Susan, 2010).

\section{- Konflik Sosial}

Setelah melakukan determinasi mengenai konflik maka kita perlu mempertajam diskursus pada terma konflik sosial. Kementrian Sosial RI (2013) mendeskripisikan bahwa konflik sosial telah ditegaskan dalam Undang-Undang No. 7 Tahun 2012 yang mencantumkan bahwa konflik sosial adalah perseteruan dan atau benturan fisik dengan kekerasan antara dua kelompok masyarakat atau lebih yang berlangsung dalam waktu tertentu dan berdampak luas yang mengakibatkan terjadinya ketidakamanan dan disintegrasi sosial sehingga mengganggu stabilitas nasional dan menghambat pembangunan nasiona. Dalam kaitan ini, ada beberapa kategori seperti; konflik keagamaan, konflik politik, konflik sumber daya alam, konflik sumber daya ekonomi, konflik komunal, konflik teritorial, konflik kelas, konflik horizontal, konflik vertikal, Konflik antar aparat dan Konflik antar pemerintahan.

Konflik keagamaan adalah konflik sosial yang terkait dengan isu-isu dan fenomena keagamaan. Fauzi dkk. (2009) mengemukakan bahwa Konflik keagamaan itu dapat mewujud dalam dua jenis aksi, yaitu (1) aksi damai dan (2) aksi kekerasan. Dalam studi y ang dilakukan Fa u zi d k k, aksi 
damai dipahami sebagai "setiap tindakan yang dilakukan tanpa kekerasan dalam rangka menanggapi isu-isu keagamaan yang menjadi sumber pertikaian di masyarakat". Termasuk di dalam aksi damai adalah aksi protes (aksi menolak suatu pandangan atau kebijakan menyangkut isu yang diperselisihkan), aksi dukungan (aksi mendukung suatu pandangan atau kebijakan menyangkut isu yang diperselisihkan), maupun aksi mediasi (tindakan yang dilakukan dalam rangka mendukung upaya penyelesaian konflik yang tengah terjadi).

Selain itu, Fauzi dkk., juga membagi isu-isu keagamaan yang menyebabkan konflik keagamaan ke dalam 6 kategori, yaitu; Pertama, isu moral, yang mencakup antara lain isu-isu di seputar perjudian, minuman keras (miras), narkoba, perbuatan asusila, prostitusi, pornografi/pornoaksi. Isu-isu moral lainnya seperti antikorupsi juga dimasukkan ke dalam isu keagamaan selama isu tersebut melibatkan kelompok keagamaan dan/atau dibingkai oleh para aktor yang terlibat dalam slogan atau ekspresi keagamaan.

Kedua, isu sektarian, yaitu isu-isu yang melibatkan perseteruan terkait interpretasi atau pemahaman ajaran dalam suatu komunitas agama maupun status kepemimpinan dalam suatu kelompok keagamaan. Dalam Islam, kelompok Ahmadiyah, Lia-Eden dan Al Qiyadah Al Islamiyah adalah di antara kelompok-kelompok keagamaan yang kerap memicu berbagai insiden protes maupun kekerasan, baik yang dilakukan oleh kelompok keagamaan maupun warga masyarakat secara umum. Sedangkan dalam komunitas Kristen, konflik kepemimpinan gereja HKBP (Huria Kristen Batak Protestan) menjadi contoh yang mewakili isu sektarian ini.

Ketiga, isu komunal, yaitu isu-isu yang melibatkan perseteruan antarkomunitas agama, seperti konflik Muslim-Kristen, maupun perseteruan antara kelompok agama dengan kelompok masyarakat lainnya yang tidak selalu bisa diidentifikasi berasal dari kelompok agama tertentu. Isu seperti penodaan agama, seperti dalam kasus karikatur tentang Nabi Muhammad, dimasukkan dalam kategori isu komunal ini. Perlu ditegaskan bahwa Perseteruan atau bentrok menyangkut suatu isu keagamaan - sepanjang kedua belah pihak yang terlibat tidak dapat diidentifikasi berasal atau mewakili komunitas keagamaan yang sama - juga dimasukkan dalam isu ini. Jika kedua belah pihak pelaku dapat diidentifikasi berasal dari komunitas agama yang sama, maka konflik semacam itu akan dimasukkan dalam kategori isu sektarian.

Keempat, isu terorisme, yaitu isu yang terkait dengan aksi-aksi serangan teror dengan sasaran kelompok keagamaan atau hak milik kelompok keagamaan tertentu, maupun serangan teror yang ditujukan terhadap warga asing maupun hak milik pemerintah asing. Tindakan kekerasan ini kerap disebut juga sebagai tindak terorisme keagamaan (religious terrorism), yang oleh Juergensmeyer dipandang sebagai "tindakan simbolik" atau performance violence, ketimbang suatu tindakan taktis 
atau strategis. Untuk kasus Indonesia, contohnya adalah pengeboman di Bali yang dilakukan oleh kelompok Imam Samudra, dan berbagai serangan bom di Jakarta. Adapun kekerasan berupa serangan teror di wilayah konflik komunal, maupun insiden yang terkait dengan upaya penyelesaian konflik di wilayah komunal tertentu seperti Poso, Sulawesi Tengah, dan Ambon, Maluku, dimasukkan dalam kategori ketiga di atas, yaitu isu komunal.

Kelima, isu politik-keagamaan, yaitu isu-isu yang melibatkan sikap anti terhadap kebijakan pemerintah Barat atau pemerintah asing lainnya dan sikap kontra ideologi/kebudayaan Barat atau asing lainnya. Termasuk ke dalam isu politik-keagamaan di sini adalah isu penerapan Syariah Islam atau Islamisme, serta pro-kontra menyangkut kebijakan pemerintah Indonesia yang berdampak pada komunitas keagamaan tertentu.

Terakhir, keenam, isu lainnya, meliputi isu subkultur keagamaan mistis seperti santet, tenung dan sebagainya, maupun isu-isu lainnya yang tidak termasuk dalam 5 (lima) kategori sebelumnya.

Dalam studinya, Fauzi dkk., membagi jenis dan bentuk insiden kekerasan keagamaan degan berbagai kategori, yaitu; dari segi jenisnya, insiden kekerasan terkait konflik keagamaan dibagi menjadi:

1. Penyerangan terhadap orang/kelompok orang

2. Penyerangan terhadap properti milik orang/kelompok orang

3. Penyerangan terhadap aparat pemerintah/properti milik pemerintah

4. Penyerangan terhadap warga asing/properti milik pemerintah asing

5. Bentrok antara warga/kelompok keagamaan vs aparat keamanan

6. Bentrok antarakelompok warga, dan

7. Kerusuhan/amuk massa berdampak pada korban jiwa/kerusakan properti milik kelompok keagamaan.

Adapun dari segi bentuknya, kekerasan/penyerangan dikelompokkan menjadi:

1. Penyisiran/pengusiran

2. Penyanderaan/penculikan/penahanan

3. Penganiyaan

4. Penganiyaan hingga tewas

5. Penembakan/pembunuhan

6. Penyitaan/penyegelan

7. Perusakan

8. Perusakan disertai penjarahan/pembakaran

9. Pengeboman

10. Penganiayaan/pembunuhan disertai perusakan/pembakaran 
Bentuk-bentuk kekerasan yang jelas menimbulkan ketegangan sosial di atas masih terus terjadi di Indonesia. Ketegangan sosial tersebut mempengaruhi sistem dan struktur sosial pada wilayah tertentu karena terjadina perubahan sosial. Jika agama tidak dapat mencari solusi atas berbagai potensi ketegangan sosial maka ketegangan sosial tersebut akan terus terjadi dan berpotensi menimbulkan konflik terbuka apalagi jika sudah ada pihak-pihak tertentu yang melakukan poitisasi isu-isu agama dengan mengaitkannya dengan isu kesenjangan dan ketidakadilan terhadap kelompok tertentu.

Pengelolaan konflik yang telah banyak dilakukan cendrung bersifat reaktif dan jangka pendek karena hanya cendrung merespon permasalahan konflik yang nampak dipermukaan dan bersifat sekunder saja sehingga secara sporadis dapat muncul kembali. Oleh karena itu, penanganan konflik yang bersifat jangka panjang untuk bisa mencegah dan meredam konflik yang terjadi merupakan suatu hal yang sangat urgen untuk dilakukan oleh semua pihak termasuk lembaga perguruan tinggi. Oleh karenanya melalui pengabdian masyarakat ini salah satu bentuk kegiatan yang akan dilakukan adalah memberikan pengetahuan, pemahaman serta keterampilan pada masyarakat khususnya pada ibu rumah tangga tentang pengelolaan potensi konflik sosial yang akan terjadi.

Melalui pelatihan tersebut maka konflik dapat dipahami dan dimaknai sebagai sesuatu yang dinamis, energik, dan fungsional selama dapat dikelolah dengan baik. Sebagaimana Lewis Coser (Sasan, 2010) yang menegaskan bahwa konflik tidak hanya bermakna negatif tapi juga bermakna positif. Karena konflik merupakan dinamisasi masyarakat yang menuju pada perubahan-perubahan sosial sebagai dampak dari konflik.

\section{KESIMPULAN}

Kesimpulan dari tulisan untuk mencegah potensi konflik yang mungkin terjadi dan menyelesaikan permasalahan yang ada maka kelembagaan yang telah dianggap berfungsi baik dalam masyarakat perlu dioptimalkan, sementara yang belum optimal dianggap perlu untuk dilakukan revitalisasi atau penguatan kembali fungsi kelembagaan dapat berkelanjutan; Masyarakat beserta stakeholder secara arif dan bijaksana dalam memahami setiap gejala permasalahan yang muncul sehingga potensi konflik yang berujung kepada kekerasan dapat dideteksi sedini mungkin. Dan; Penguatan Modal Sosial termasuk Nilai-nilai kearifan lokal yang sudah ada dalam masyarakat.

\section{REFERENSI}


Horton, Paul B dan Hunt, Chester L. 1993. Sosiologi. Edisi keenam. Jilid 1. Jakarta: Erlangga.

Nasikun, DR. 2005. Sistem Sosial Indonesia. PT. RajaGrafindo Persada. Jakarta.

Radjab, Mansyur,dkk 2015. Pelatihan Pemetaan Partisipatif : Sebagai Upaya Komunitas Petani Dalam Mengidentifikasi Permasalahan Produksi Rumput Laut di Desa Baruga Kecamatan Pajukukang Kabupaten Bantaeng.(Laporan Hasil Pengabdian Masyarakat). LP2M Unhas.

Saefullah, Budi Yana. 2003. Modul Pelatihan Pengorganisasi Masyarakat. Institute For Civil Society (INCIS). Jakarta

Data Dinas Sosial Provinsi Sulawesi Selatan Tahun 2014 